\title{
Flora da Reserva Ducke, Amazonas, Brasil: Tiliaceae
}

Gerleni Lopes Esteves ${ }^{1}$

Schumann, K. 1886. Tiliaceae. In: C. F. P. Martius \& A. G. Eicher (eds.). Fl. bras. 12(3):117-200, tabs.25-39.

Burret, M. 1926. Beiträge zur Kenntnis der Tiliaceen. Notizbl. Bot. Gart. Berlin-Dahlem, 9:592-880.

Seter, H. L. 1977. A revision of neotropical Tiliaceae: Apeiba, Luehea and Lueopsis. Tese de Doutorado. University of Kentucky. 207p.

Árvores altas; indumento dos ramos e folhas constituído de tricomas estrelados e/ou simples. Folhas simples, alternas; lâminas inteiras. Inflorescências cimosas. Flores monoclinas; epicálice presente em Lueheopsis; sépalas 5 , valvares, livres entre si; pétalas imbricadas; estames numerosos; filetes conatos na base formando o tubo estaminal; anteras 2tecas, 4-esporangiadas, rimosas; estaminódios presentes ou ausentes; ginóforo presente ou ausente; ovário 2-muitos lóculos; óvulos (1-)2- muitos por lóculo; estiletes colunares ou divididos em tantos ramos quantos forem os carpelos; estigmas lobados ou denteados. Frutos capsulares, lisos ou recobertos de acúleos, deiscência loculicida ou poricida. Sementes aladas ou não; embrião reto ou curvo; cotilédones em geral foliáceos.

Família com cerca de 50 gêneros e 450 espécies predominantemente tropicais. Na flora da Reserva Ducke ocorrem duas espécies: Apeiba echinata e Lueheopsis rosea.

\section{Chave para os táxons de Tiliaceae da Reserva Ducke}

1. Face abaxial das lâminas foliares densamente recoberta de tricomas estrelados minúsculos, alvos e ferrugíneos misturados; flores sem epicálice; estaminódios petalóides; ginóforo presente; cápsulas, recobertas de acúleos, globoso-achatadas, com deiscência poricida ......

1. Apeiba echinata

1'. Face abaxial das lâminas foliares lanuginosa, inteiramente ferrugínea; flores com epicálice; estaminódios fimbriados; ginóforo aussente; cápsulas desprovidas de acúleos, recobertas de tricomas estrelados, oval-oblongas, com deiscência loculicida na metade apical ....... 2. Lueheopsis rosea

\section{Apeiba}

Apeiba Aubl. Hist. pl. Guiane. 1:536, 1775.

Árvores altas, tronco sem sapopemas; indumento dos ramos e folhas pubescente. Folhas pecioladas, lâminas inteiras. Inflorescências opositifólias. Flores pediceladas; epicálice ausente; sépalas livres entre si, oval-lanceoladas; pétalas obovadas, ápice arredondado; estames numerosos; filetes concrescidos na base; anteras lineares, com extensão apical estéril bifurcada, tecas paralelas entre si; estaminódios presentes; ginóforo presente; ovário sub-globoso, multilocular, multiovulado por lóculo; estiletes colunares; estigmas curtamente denteados. Cápsulas globoso-achatadas, recobertas de acúleos, deiscência poricida. Sementes globosas, não aladas; embrião reto; cotilédones foliáceos.

Gênero neotropical com cerca de sete espécies predominantemente arbóreas.

1.1 Apeiba echinata Gaert. Fruct. 2 (121): 189. 1802.

Árvores $15-25 \mathrm{~m}$ alt.; tronco $20-30 \mathrm{~cm}$ diâm. Folhas com pecíolos de 1,3-2,5 cm compr.; lâminas 7,2-16×3,7-5,7 cm, elípticas a oblongas, ápice longamente atenuadoacuminado, margem levemente crenada a serreada na porção apical, quase inteira na porção basal, 5-nervadas na base, nervuras laterais 5-7, escuras, face adaxial nigrescente, quase glabra, com tricomas estrelados esparsos sobre as nervuras, face

$\overline{{ }^{1} \text { Instituto de Botânica de São Paulo, C.P. 4005, CEP 01061-970, São Paulo, SP, Brasil. gerleniibot@ yahoo.com.br }}$ 
abaxial esverdeada, com tricomas estrelados minúsculos alvos e ferrugíneos, entre as nervuras basais e laterais tufos de tricomas estrelados ferrugíneos. Flores com pedicelos até $1 \mathrm{~cm}$ compr.; sépalas ca. $2 \mathrm{~cm}$ compr., carnosas, cuculadas na parte apical, amarelas; pétalas 1,3-1,5 cm compr., largamente obovadas, amarelas; filetes curtos; estaminódios menores que os estames, petalóides; ginóforo curto. Cápsulas 6-7 cm diâm., acúleos uncinados, escuros, glabros, delgados.

Venezuela, Guiana, Suriname, Guiana Francesa e Norte do Brasil.

Floresta de baixio.

Nome local: pente de macaco.

3.XI.1994, Ribeiro et al. 1483 (INPA, SP).

Material adicional examinado: 11.VIII.1966(fr.) Rodrigues \& Osmarino 822 (INPA); 15.IV.1966 (fr.) Rodrigues \& Coelho 7686 (INPA).

Espécie facilmente reconhecida pela presença de um tufo de tricomas estrelados na axila das nervuras basais e laterais das lâminas foliares.

\section{Lueheopsis}

Lueheopsis Burret, Beiträge zur Kenntnis der Tiliaceen. Notizbl. Bot. Gart. Berlin-Dahlem, 9: 838. 1926.

Árvores; indumento constituído de tricomas estrelados. Folhas curtamente pecíoladas; lâminas inteiras. Inflorescências axilares e terminais; flores curtamente pediceladas; epicálice gamofilo, lobado; cálice com comprimento maior que o epicálice; sépalas livres entre si, carnosas; pétalas com tricomas estrelados na base; estames numerosos, agrupados em falanges conatas na base formando o tubo estaminal; anteras 2-tecas, lineares, rimosas, tecas divergentes na metade apical; estaminódios 5, fimbriados; ginóforo ausente; ovário 5-locular, multiovulado por lóculo; estiletes colunares, levemente dilatado na porção apical; estigmas 5-lobados. Cápsulas sublenhosas, sem acúleos, pubescentes a glabrescentes, tricomas estrelados, deiscência loculicida na metade apical. Sementes ovóides; embrião reto, cotilédones foliáceos.
Gênero com cerca de cinco espécies distribuídas na região neotropical.

2.1 Lueheopsis rosea (Ducke) Burret. Notizbl. bot. gart. Berlin-Dahlem, 9: 840. 1926.

Árvores 18-20 m alt.; tronco tortuoso; ramos jovens densamente recobertos de tricomas estrelados, glabrescentes. Folhas com pecíolos de 0,5-10 mm compr.; lâminas 9,5-29 ×4,3-10 cm, obovadas a largo-elípticas, ápice atenuado-acuminado, base obtusa, margem inteira na porção basal, esparsamente serreada na porção apical, dentes proeminentes, 3-nervadas na base, nervuras laterais ca. 4 (incluindo as basais), discolores, face adaxial glabra, face abaxial lanuginosa, ferrugínea. Flores com pedicelos de 3-4 mm compr., pubescentes, ticomas estrelados ferrugíneos; epicálice ca. 3 mm compr., 6-lobado, ferrugíneo, lobos oval-agudos; sépalas 9-12 mm compr., róseas, face dorsal pilosa, face ventral glabras; pétalas 12-14 mm compr., lilás; tubo estaminal glabro, estaminódios maiores que os estames. Cápsulas ca. 3 cm compr., oval-oblongas, rostradas; sementes aladas.

Guiana, Suriname, Guiana Francesa e Norte do Brasil (Amazonas, Pará).

Floresta de vertente e de platô.

Nome local: açoita-cavalo.

17.VII.1995, Sothers et al. 521 (INPA, SP); 15.VII.1995, Hopkins et al. 1572 (INPA, SP); 11.VIII.1995, Ribeiro et al. 1100 (INPA); 23.VIII.1995, Assunção \& Pereira 229 (INPA); 11.X.1994, Vicentini et al. 729 (INPA); 11.VIII.1995, Costa et al. 341 (INPA, SP); 8.VIII. 1997, Assunção et al. 603 (INPA, SP).

Lueheopsis rosea assemelha-se a $L$. dukeana por ambas apresentarem a face abaxial das folhas lanuginosas e as sépalas glabras na face ventral, entretanto, pode ser distinta pelos ramos floridos, pedicelos e epicálice recobertos de tricomas estrelados minúsculos e pelas flores comparativamente menores com o epicálice lobado até a metade do seu comprimento total; ao passo que $L$. dukeana apresenta os ramos floridos, pedicelos e epicálice vilosos, as flores comparativamente maiores, com epicálice curtamente lobado. 